\title{
Phenomenon of Genesis of Papillae Pattern Prints on Human Skin
}

\author{
Dr. iur. Annika Lall \\ ORCID: 0000-0001-8907-5057 \\ Retired Police Lieutenant Colonel, Estonia \\ annika.lall@gmail.com \\ Mg. iur. Aelita Zïle \\ ORCID: 0000-0002-4378-738X \\ Rìga Stradiṇš University, Faculty of Law, Latvia \\ Aelita.Zile@rsu.lv
}

\begin{abstract}
Papillae pattern prints play an essential role in identification of a person. However, their presence on the object found at the scene does not mean that the identified person committed a specific crime or participated in the concealment of the crime. Therefore, no less important is the object on which there are possible papillae pattern prints left, the mechanism of formation and location of them on the object. The skin of a victim, on which one can visualise the papillae pattern prints, can be one of such objects. However, there is a number of factors that may affect the genesis of papillae pattern prints on human skin that one cannot have an impact on. Identifying study and analysis of such factors may affect testing and introduction of visualisation methods of such prints.
\end{abstract}

Keywords: skin, papillae pattern print, formation mechanism of prints.

\section{Introduction}

The functions of the skin (cutis) as the largest human organ are to protect the body from mechanical, chemical and thermal effects, as well as from microorganisms, to regulate body dehydration and body temperature, to participate in the general immune defence system of the body, to provide individual sensations such as touch, position, temperature, pain and feeling of pressure [4, 392]. 
In forensics, on the other hand, the skin plays an equally important role in solving criminal offenses.

The scientist Mironov (А. И. Миронов) in his monograph "A Trasological Study of the Skin Relief of the Human Traces" indicated that the skin area of an adult is about $16,000 \mathrm{~cm}^{2}$, and the papillae pattern area is about $850 \mathrm{~cm}^{2}$, which is about $5 \%$ of all skin area $[16,3]$.

According to him, when using the dactyloscopic examination method, only about $5 \%$ of human skin is used to identify a person, but Mironov's study of the relief of human skin showed that both theoretically and practically a person can be identified by the skin relief left on any part of his/her body. This means that it is possible to identify a person at the scene by recovering the trace with the skin relief, for example, the prints of the palm and fingers, of the elbow, knee, cheek or forehead. Although Mironov's research significantly expanded the possibilities of identification of a person, he also studied human skin only as a trace-forming object by using the method of trasological research.

Human skin as a trace-forming object is known to criminalists from both dactyloscopic and trasological aspect. However, criminalists are interested in human skin not only as a trace-forming but also as a trace-bearing object [11, 228-229].

This is due to the fact that under certain conditions papillae pattern prints may be left on human skin, for example, at the time of the commitment of a crime (mechanical asphyxia, necrophilia), in case of concealment of it (dissection of a corpse, transfer of a corpse).

Human skin as a trace-forming object plays a very important role in detection and solving the crime, because the presence of papillae pattern prints on human skin indicates the process of interaction between human skin as a trace-forming object and human skin as a trace-bearing object (any other part of the human body) [9, 312].

\section{Human skin relief}

Papillary lines form the skin relief on palms and fingers, soles and toes of a person.

The height of the papillary lines is $0.1-0.4 \mathrm{~mm}$, the width is $0.2-0.7 \mathrm{~mm}$, and the width of the interpapillary line cavity is $0.1-0.3 \mathrm{~mm}[15,8]$.

There are output channels of sweat glands - pores - with a diameter of 0.08 to $0.25 \mathrm{~mm}$ on the surface of papillary lines. There are $9-18$ pores on $1-\mathrm{cm}$-long papillary line surface, along which sweat emerges from the body. In cross section, papillary lines have a trapezoidal shape with a wavy upper base [13, 39].

On those parts of the human body, on the other hand, where there are no papillae patterns, the skin relief is formed by protrusions, cavities and pores of different type, size and configuration, which, in turn, create a unique and individual skin relief [8,223-224].

If one looks closely, one can see that the pores are randomly located in these parts of the body and in some places, they act as intersections, respectively, the pores are connected to each other by wrinkles of different size, forming geometric shapes that can be considered as small areas of skin. Wrinkles, in turn, form a kind of network of wrinkles. 
Annika Lall, Aelita Zìle. Phenomenon of Genesis of Papillae Pattern Prints on Human Skin

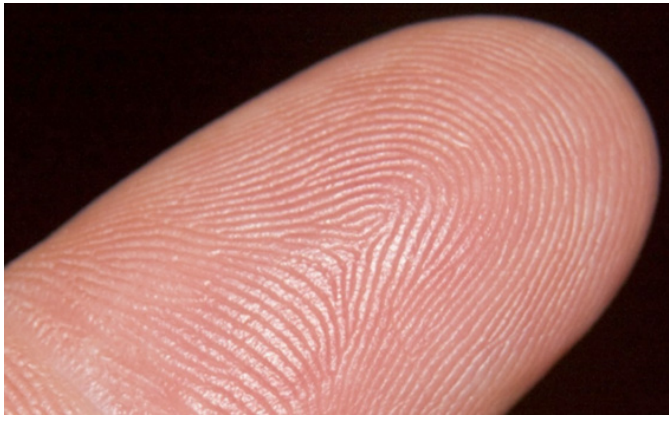

Figure 1. Papillae pattern on the finger [17]

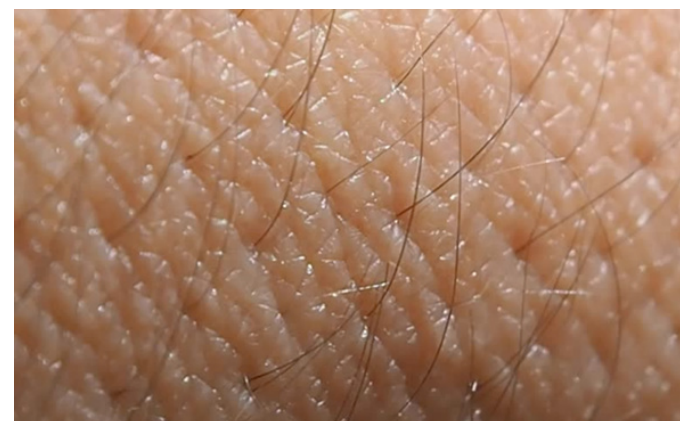

Figure 2. Human skin relief [18]

These skin areas can be triangular, quadrangular, and diamond-shaped, as well as polygons of various shapes. However, this does not mean that four connected pores form only a quadrilateral, they can also be connected diagonally, forming four triangles inside this quadrilateral, or the wrinkle just crosses the figure, connecting the pores behind it, or this wrinkle bursts into one or another figure. This division of relatively large geometric shapes into smaller geometric shapes is very common, but there are also relatively large geometric shapes that are not divided into smaller ones. Like the protrusions and cavities of the papillae pattern, the skin areas form a relatively independent and individual set of identifying features in the form of a complex network of cavities of different sizes between the skin areas $[8,224]$.

\section{Papillae pattern print forming objects and classification of traces}

At least two objects participate in the trace formation - a trace-forming object and a trace-bearing object, but most often the trace is formed by three objects - a traceforming object, a trace-bearing object and a trace-forming substance [14, 15].

In his monograph "Fundamentals of Trasology", scientist Grigory Granovsky pointed out that there are entire groups with objects that practically cannot be tracebearing objects. For example, papillae pattern prints on the hands and legs will always be trace-forming objects $[14,16]$.

Scientist Igor Indulens in the monograph "The Forensic Doctrine of Traces" also pointed out that papillary lines have a rather fine relief, and therefore they can leave their traces only on the surface with an even thinner relief, i.e. on practically smooth surfaces $[1,22]$.

In turn, in the publication "A Conventional Method for Lifting Latent Fingerprints from Human skin Surfaces" scientists Reichardt, Carr and Stone experimentally left a papillae pattern print on a papillae pattern of the central part of the palm. The trace was left by papillary lines covered with oil on the clean part of the palm. The trace was then 
visualised with a dark dactyloscopic powder [4, 140]. Although the trace was left experimentally, the fact itself allows to refute the stated. If one looks closely at the trace visualised, one will see that the papillary lines of the palm are also slightly visualised, which confirms that the pattern of papillary lines from the finger is reflected in the papillae pattern on the palm. It must be admitted that the good reflection of the trace was facilitated by an oil coating, the adhesive properties of which significantly exceed the properties of the sweat-grease substance on the surface of the palm.

All three trace-forming objects are involved in the process of forming papillae pattern prints on human skin: the trace-forming object - papillary lines, the trace-forming substance - sweat-grease substance and the trace-bearing object - human skin on any part of the body.

Trace-forming sweat-grease substance is made of sweat, grease and dead cells of the epidermis.

Sweat glands (glandulaesudoriferae) are very numerous (500-1000 on one square centimeter of skin. They are distributed unevenly: especially there are a lot of them on the palms, armpits, groin area [6, 14].

There are two types of sweat glands in the skin - apocrine and merocrine (there are more). They differ in structure, mechanism of secretion and location in the skin. Apocrine sweat glands are located on human skin covered with hair, for example, in the armpits, in the external genitalia and nipples of the breast. Merocrine sweat glands are everywhere in the skin where there are no apocrine sweat glands. The functional activity of the merocrine glands depends on various factors: the secretion of the glands in soles or palms - mainly on physiological factors such as stress, less on the temperature, while elsewhere in the skin the secretion is determined by temperature. $[5,400]$

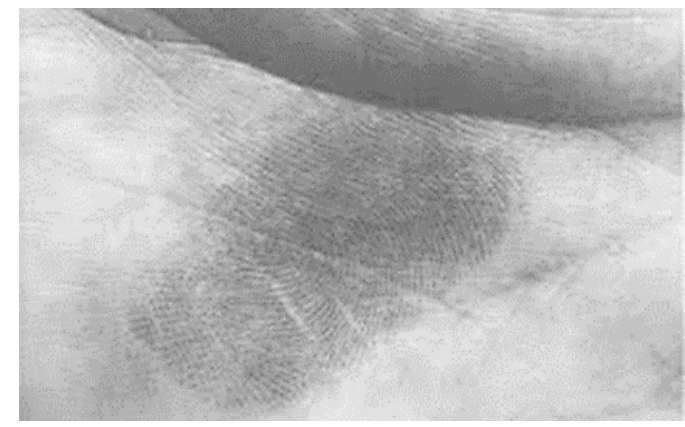

Figure 3. Normal, oily latent print experimentally deposited on a clean friction ridge area and then developed $[4,140]$

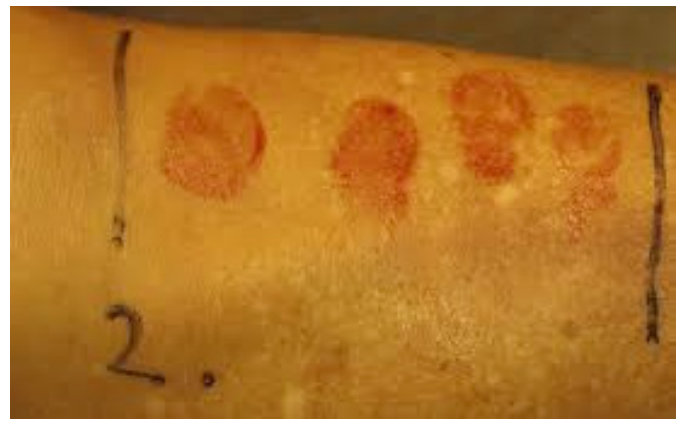

Figure 4. Second group of bloody fingerprints on cadaver skin before processing $[2,820]$ 
Thus, the question arises about the inclusion of fat into the sweat-grease substance. This can be explained by the fact that they knowingly or unknowingly touch other parts of the body that contain this fat and also the dead cells of the epidermis, which when mixed also form sweat-grease substance, which is substance that forms the papillae pattern print. Also, in the process of forming a trace, one applies their sweat-grease substance to the trace-bearing surface, but separates the substance already on it, because, as one knows, in nature there is no completely pure surface, which means that any surface is completely or partially covered with the substance. From this it can be concluded that the sweat-grease substance forming the papillae pattern print is not pure, by which it is meant that this is not the sweat-grease substance of one person but the substance with an admixture of other substances.

According to the trace-forming object, papillae pattern prints are considered as homeoscopic traces, they are traces where one of the parts of the human body is the object forming the trace. In turn, after changing the surface of the trace-bearing object, the traces can be divided into volumetric and superficial.

Volumetric traces are three-dimensional traces in which a trace-forming object causes constant deformation in a trace-bearing object. In the process of forming of volumetric traces it is very important that the degree of hardness of the trace-forming object is higher than the degree of hardness of the trace-bearing object, since only then the protruding parts of the trace-forming object could penetrate the trace-bearing object and create residual deformation in it $[14,16]$.

The formation of volumetric papillae pattern prints on human skin can occur as a result of a strong grip. However, when releasing the grip, the skin takes its previous position, and traces of volumetric papillae pattern prints are no longer visible, and this process, the skin taking its natural position after a strong grip, occurs within a few seconds. The studies conducted by the Author confirmed that the period of time during which these volumetric papillae pattern prints are visible depends on the pressure force with which the grip is made and the roughness of the papillary lines. This means that the volumetric papillae pattern prints will remain longer on the skin of a living person, they will be formed with a rougher (more pronounced) papillae pattern and greater pressure force. Of course, this depends on the pressure force with which the grip was made, but one cannot talk about dactyloscopic examination of such traces due to the fact that these traces cannot be fixed and preserved under the influence of the time dimension. Thus, papillae pattern prints as volumetric traces on human skin are mainly of theoretical significance. The reason for this conclusion is the temporary preservation of these traces $[12,536]$.

Overlapping traces can be formed on human skin, firstly, with sweat-grease substance that naturally covers papillary lines. Secondly, papillae pattern prints are additionally covered with some other substance, for example, cream, oil, blood. Equally important is the division of the traces by visibility. Papillae pattern prints left by a sweat-grease substance on human skin are invisible (latent), but if the papillary lines were covered, for 
example, with blood, the trace may be poorly visible or visible. The degree of visibility of the trace will depend on the concentration of the trace-forming substance.

In practice, there may be cases where the trace can be combined. This means that:

- one part of the trace can be visible, and the other - poorly visible;

- one part of the trace can be visible, and the other - latent;

- one part of the trace can be poorly visible, and the other - latent;

- one part of the trace can be visible, the other - poorly visible, and the third - latent.

Such combinations of traces, however, facilitate their search, but their complex visualisation process can be difficult, since it can be different for each part of the trace $[10,414]$.

\section{Mechanism of formation of papillae pattern prints and factors having impact on the quality of traces}

The presence of papillae pattern prints on human skin undeniably proves the fact of contact and indicates the place of contact and the possible mechanism of trace formation, such as grip. Traces of the grip on the neck can be detected when strangled by the hand.

Manual strangulation is considered a $100 \%$ murder. It is characterised by the following external features:

- circular hemorrhages following fingerprints, which in some cases are arranged in series and help to determine the position of the fingers during strangulation strangulation from the front or back;

- crescent-shaped abrasions from nails. If the neck moves quickly, nails can cause longer linear scratches. If the neck is squeezed with a scarf or other soft interlayer, the outer traces may be absent;

- damage due to resistance $[7,436]$.

These external features already indicate the possible location of the papillae pattern prints, but they do not allow identifying a person, yet a sufficient number of particular features of the papillae pattern, their location and mutual arrangement form an individual set of particular features of the papillae pattern, which is the basis for recognising the papillae pattern valid for identification of a person.

Traces of pressure can be detected, for example, while compressing the chest and abdomen at the same time. Death of an infant can be achieved by squeezing the chest and abdomen even with the palms [7,437].

The traces of the grip when moving the corpse can be located on the ankles and on the forearm in the wrist area, as well as on other parts of the body when the victim has been caught at the time of the crime or after concealing the traces of the crime.

Between 2014 and 2016, a series of experiments was carried out in Estonia and Latvia, the purpose of which was to study and analyse the appearance of grip traces on 
human skin. The aim of the experimental series in Estonia was to simulate the movement of the corpse and use the direct dusting method to visualise possible papillae pattern prints, but in Latvia the aim was to simulate the grip in the forearm and to use the direct transfer method to visualise them (before the visualisation of the papillae pattern print it has been copied on glossy paper - Kromekote card [4, 137] ). In both series of experiments, only natural sweat-grease substance on the palms and fingers was used to leave papillae pattern prints, as well as the mechanism of trace formation was closely aligned with the real situation.

Twelve people - 11 men and 1 woman aged 22-35 - took part in an experiment of the corpse displacement simulation. Two men acted as movers. The movers were in good physical condition, weighing $85 \mathrm{~kg}$ and $125 \mathrm{~kg}$. In turn, the body weight of the body of a woman to move was $55 \mathrm{~kg}$, of two men $-73-75 \mathrm{~kg}$, of other two men $-82-85 \mathrm{~kg}$, of three men - 90-95 kg, of two men - 97.5-103.4 kg. The transfer distance was $22 \mathrm{~m}[2,114]$.

During the experiment of simulation of moving the corpse, it was found that the heavier the person being moved was, the more the hands of the movers were sweating, so the grip was repeatedly performed, resulting in the layering and overlapping of papillae pattern prints $[2,114]$.

Twelve persons - 9 women and 3 men aged 21-24 - were involved in the grip simulation experiment and they were simulating the grip. Twelve persons -6 women and 6 men aged 21-24 were caught in the forearm area and whose skin was both smooth and hairy and without hair $[2,115]$.

Having studied the mechanism of formation of papillae pattern prints used during both experimental series, it was found that the quality of the traces is significantly influenced by the pressure force applied during leaving them, as well as the condition of the skin on which the traces are left $[2,119]$.

During the experiment it was also found that the choice of the visualisation method of papillae pattern prints has an impact on the final result because 26 papillae pattern prints were left during grip simulation, but applying the direct transfer method no papillae pattern prints were detected $[2,121]$.

The quality of papillae pattern prints can also be significantly affected by depletion of sweat-grease substance. This is observed if papillae pattern prints are left several times with the same part of the hand, thus preventing regeneration of sweat-grease substance because when leaving the traces, this substance stratifies on the skin area with which the place of papillae pattern has been in contact.

\section{Conclusions}

Having studied and analysed the mechanism of formation of papillae pattern prints and its effect on the quality of them, it can be concluded that one cannot have an impact practically on any of these factors. 
Firstly, speaking on the trace-forming object (papillary lines) and the traceforming substance - the more pronounced the papillary lines and the more richly they are covered with sweat-grease substance (or some other substance), the more likely it is that traces of papillae pattern prints will be left. While repeatedly making the grip, the depletion of sweat-grease distance happens and the overlapping of papillae pattern prints takes place.

Secondly, it is the condition of the trace-bearing object (skin). If the skin is smooth and hairless, then it will better perceive the papillae pattern print. However, this does not preclude the possible formation of papillae pattern prints on the skin with a small amount of hair and wrinkles.

Thirdly, it is about the nature of the contact and its duration between the traceforming object and trace-bearing object. The nature of the contact means the position of the trace-forming object and trace-bearing object at the moment of contact. The traceforming object with the trace-bearing object has both been in a moving position, or the trace-bearing object has been in a stationary position relative to the trace-forming object. The nature of the contact can also affect the duration of the contact.

Fourthly, it is the nature of the actions to be taken, for example, when moving a corpse, the weight of the corpse in relation to the physical condition of the mover is significant.

\section{Papillārlīniju rakstu pēdu ǵenēzes fenomens uz cilvēka ādas}

\section{Kopsavilkums}

Papillārlīniju rakstu pēdām ir būtiska loma personas identifikācijā. Tomēr to atrašanās uz kāda objekta, kas atrasts notikuma vietā, vēl nenozīmè, ka identificētā persona ir izdarījusi konkrēto noziedzīgo nodarījumu vai ñēmusi dalību noziedzīga nodarījuma slēpšanā. Tāpēc ne mazāk svarīgs ir objekts, uz kura ir atstātas iespējamās papillārlīniju rakstu pēdas, un jautājums, kāds ir pēdu veidošanās mehānisms un izvietojums uz objekta. Viens no šādiem objektiem varētu būt upura āda, uz kuras ir iespējams vizualizēt papillārlīniju rakstu pēdas. Tomēr pastāv vairāki faktori, kas var ietekmēt papillārlīniju rakstu pēdu genēzi uz cilvēka ādas un kurus mēs nevaram ietekmēt. Šādu faktoru apzināšana, izpēte un analīze varētu ietekmēt šo pēdu vizualizēšanas metožu aprobēšanu un ieviešanu praksē.

Atslēgvārdi: āda, papillārlīniju raksta pēdas, pēdu veidošanās mehānisms. 
Annika Lall, Aelita Zìle. Phenomenon of Genesis of Papillae Pattern Prints on Human Skin

\section{Literature}

1. Indulēns, I. 1972. Kriminālistiskā mācība par pēdām (Eng. The Forensic Doctrine of Traces). Rìga: Pētera Stučkas LVU redakcijas un izdevniecības daḷa.

2. Lall, A., Zile, A. 2016. Experimental Series of Trace Formation on Human Skin During Arm Grip and Body Transportation. International Research and Practice Juridical Journal Criminalist, 12.

3. Petretei, D., Angyal, M. 2015. Recovering Bloody Fingerprints from Skin. Journal of Forensic Identification. 65(5).

4. Reichard, G. J, Carr, J. C., Stone, E. G. 1978. A Conventional Method for Lifting Latent Fingerprints from Human skin Surfaces. Journal of Forensic Sciences, 23(1). doi:10.1520/JFS10662J.

5. Rūmanss, G. M., Kažoka, Dz., un Pilmane, M. 2019. Klīniskā anatomija medicīnas studentiem (Eng. Clinical Anatomy for Medical Students). Rìga: RSU.

6. Šmits, A. u. c. 1976. Populārā medicīnas enciklopēdija (Eng. The Popular Encyclopedia of Medicine). Rīga: Zinātne.

7. Teteris, O. 2004. Tiesu medicinas esence (Eng. The Essence of Forensic Medicine). Rìga: Rasa ABC.

8. Zīle, A. 2014. Cilvēka āda kā pēdu atstājējobjekts un pēdu uztvērējobjekts: teorētiskie un praktiskie aspekti (Eng. Theoretical and Practical Aspects: Human Skin as Trace-forming and Tracebearing Object). Valsts policijas koledžas III Starptautiskās zinātniskās konferences materiāli. Rīga: Valsts policijas koledža.

9. Zīle, A. 2018. Eksperimentālā sērija latentu papillārlīniju rakstu pēdu vizualizēšanā un izṇemšanā no miruša cilvēka ādas (Eng. Experimental Series of Visualisation and Recovery of Latent Papillae Pattern Prints from the Skin of a Dead Person). Rigas Stradina universitāte. 2018.gada zinätniskā konference. Tēzes.

10. Zīle, A. 2011. Fizikālo metožu pielietošanas priekšnosacījumi un problemātika papillārlīniju rakstu pēdu vizualizēšanas procesā uz līḳa (Eng. Preconditions for the Use of Physical Methods and Problematics of Visualisation Process of Papillae Pattern Prints on a Corpse). Starptautiskās jauno pētnieku un studentu zinātniski praktiskās konferences "Izaicinājumu un iespēju laiks: problēmas, risinājumi, perspektīvas" rakstu krājums. Rēzekne: SIA “Etra”.

11. Zīle, A. 2014. Joda tvaiku metode un tās pielietošanas iespējas papillārlīniju rakstu pēdu vizualizēšanā uz cilvēka ādas (Eng. Iodine Fuming and Possibilities of its Usage for Visualisation of Papillae Pattern Prints on Human skin). Daugavpils Universitātes Sociālo zinātñu fakultātes Starptautisko zinātnisko konferenču rakstu krājums. "Sociālās zinātnes reǵionālajai attīstībai 2013". Daugavpils: Akadēmiskais apgāds "Saule".

12. Zīle, A. 2013. Papillārlīniju rakstu pēdu uz dzìva cilvēka ādas vizualizēšanas teorētiskie un praktiskie aspekti (Eng. Theoretical and Practical Aspects of Visualisation of Papillae Pattern Prints on Skin of a Living Human Being). Daugavpils Universitātes 54. starptautiskās zinātniskās konferences materiāli. Daugavpils: Akadēmiskais apgāds "Saule".

13. Анарионова, В. А., Евсиков, В. Н., Зуев Е. И., Теткин С. И. 1957. Сборник работ по криминалистике (дактилоскопические исследование), № 2 (Eng. Forensic Work Collection (Dactyloscopic Study), No.2). Москва: МВА СССР Научно-исследовательский институт милиции.

14. Грановсий, Г. А. 1965. Основы трасологии. Общая часть (Eng. Fundamentals of Trasology (General Part)). Москва: МООП СССР Всесоюзный Научно-исследовательский институт Охраны общественного порядка. 
Annika Lall, Aelita Zìle. Phenomenon of Genesis of Papillae Pattern Prints on Human Skin

15. Кудинова, Н.С. 2018. Криминалистика: основы современной дактилоскопии (Eng. Forensics: Fundamentals of Modern Dactyloscopy). Саратов: Саратовский социально-экономический институт (фикиац) РЭУ им. Г. В. Пиеханова.

16. Миронов, А. И. 1968. Трасологическое исследование следов рельефа кожи человека (Eng. A Trasological Study of the Skin Relief of the Human Traces). Москва: МООП СССР Всесоюзный Научно-исследовательский институт Охраны общесрвенного поряАка.

17. https://m.sibenik.in/zanimljivosti/prsta-moze-otkriti-o-vama/59960.html [accessed on 06.08.2020.]

18. https://www.shutterstock.com/video/clip-1014497798-human-skin-hairs-macro-close-viewgrowth [accessed on 09.09.2020] 